\title{
心脳卒中および虚血性心脳症の病理学的研究 $(\mathrm{V}) *$
}

一心筋梗塞症における脳の病理学的検索, 基底核を中心として—

\begin{tabular}{|c|c|c|}
\hline 衛** & 飯田 & 正美** \\
\hline 昌夫** & 鈴木 & 恒道** \\
\hline
\end{tabular}

冲中ら ${ }^{1)} に よ り$ 提唱された心脳卒中の概念は以 後藤井ら ${ }^{2)}$ にり「脳卒中様症状を呈する非定型 的心筋梗塞症として把握されており, 脳に粗大病 変を認める例と認めない例が報告されている，心 脳卒中の病態を明らかにする上において，脳卒中 例の心病変の検討と, 心筋梗塞例の脳病変の検討 との両者が必要であると考えられる．脳卒中例の 心病変については飯田 ${ }^{3)}$, 加藤4) らにより「脳梗 塞例では脳出血例に比べ，心筋梗塞を含め高度の 心筋線維化という虚血性病変の発現が高率に認め られ, 又, 脳梗塞の分類 ${ }^{5)}$ では小軟化群に多い」 という特徴が明らかにされ, 心脳卒中例では「基 底核を中心とした小軟化多発例が多い」と報告さ れた. 今回心筋梗塞例について, 病理学的検索を 加え, 特に脳に肉眼的変化を認めない症例におけ る顕微鏡的変化を観察するため，基底核を中心と して検討を加えた。

\section{研究方法}

日本医科大学病理学教室における昭和46年から 52 年までの心筋梗塞例で脳の検索可能な症例 27 例 について検討し, その内の肉眼的非軟化群につい て更に検索を加えた.

脳組織は武谷の方法 ${ }^{6)}$ により切出し, フォルマ リン固定, パラフィン包埋, 薄切後, HE 染色, アザン染色, PAM 染色, エラスチカ染色, LFB 染色を使用した.

*1978年 5 月第10回日本動脈硬化学会において発表

** 日本医科大学第 1 病理学教室
軟化群に関しては肉眼的変化を中心とし, 非軟 化群に関しては基底核を, 淡蒼球, 被款, 尾状核, 視床, 外包, 内包に分け各々について, 神経細胞 の変化, 血管周囲性変化, 脱髄及び軟化の 3 項目 について程度を検索し, 更に心筋梗塞発作時から 死亡するまでの時間を 4 群に分け, 1 日以内のも のを I 群, 1 週間以内のものを II 群， 2 週閒以内 のものを III 群, それ以上のものを IV 群とし, それ以外に今回死亡を直接に関係のない古い心筋 梗塞の認められる群を陳旧性病変群として比較検 討した. 神経細胞の変化については成書の不可逆 性変化 ${ }^{7,8)}$ を参考にし, 血管周囲性変化について はその血管の周囲の細胞変化と大きさ及び数によ り，脱髄及び軟化ではその範囲の大きさにより， 更に各々を(一)〜 ( 冊)の 5 段階に分け $( \pm+)$ を軽 度，（井）を中等度，（卅）を高度とした。

\section{結 果}

心筋梗塞例27例の脳の肉眼的変化を検討してみ ると, 小軟化群が 9 例で他に脳出血例, クモ膜下 出血例, 大軟化例は認められなかった (Table 1). 軟化群について心臓の変化を検索してみると

Table 2 のようであった.

非軟化群について一部欠損のある脳 2 例を除く 16例を検索してみると以下の如くになった.

(1) 神経細胞の変化では, 中等度以上の変化が 陳旧群より急性群にややびまん性にみられた (Table 3).

(2) 血管周囲性変化では, 急性群の淡蒼球, 被 
Table. 1

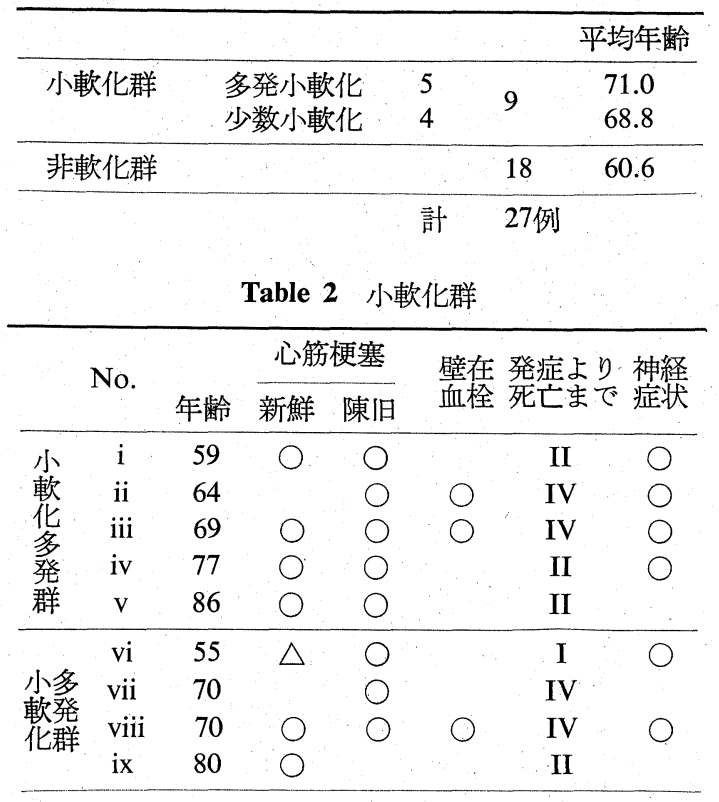

Table. 3 神経細胞変化

\begin{tabular}{|c|c|c|c|c|c|c|}
\hline $\begin{array}{l}\text { 時 } \\
\text { 間 }\end{array}$ & No. & $\begin{array}{l}\text { 年 } \\
\text { 齢 }\end{array}$ & 淡蒼球 & 被殼 & 尾状核 & 視床 \\
\hline \multirow[t]{4}{*}{ I } & 1 & 48 & WI & $\mathrm{H}$ & $H$ & $H$ \\
\hline & 2 & 58 & $H$ & $H$ & $H$ & $H$ \\
\hline & 3 & 58 & $H$ & $H$ & + & $H$ \\
\hline & 4 & 58 & $H$ & $H$ & H & + \\
\hline II & 5 & 60 & + & $H$ & + & + \\
\hline \multirow[t]{2}{*}{ III } & 6 & 54 & $H$ & + & + & $H$ \\
\hline & 7 & 81 & + & $H$ & + & H \\
\hline IV & 8 & 50 & $\mathrm{~m}$ & $H$ & $H$ & $H$ \\
\hline 陳 & 9 & 45 & + & it & + & + \\
\hline 旧 & 10 & 48 & m & $H$ & $H$ & + \\
\hline \multirow[t]{6}{*}{ 性 } & 11 & 56 & W & + & + & $H$ \\
\hline & 12 & 60 & + & + & + & + \\
\hline & 13 & 69 & H & + & H & + \\
\hline & 14 & 71 & $H$ & + & $H$ & + \\
\hline & 15 & 72 & H & H & $H$ & m \\
\hline & 16 & 79 & $H$ & + & $H$ & + \\
\hline
\end{tabular}

殼に中等度以上の変化がみられ，陳旧群の被殼， 尾状核にも同様な変化がみられた (Table 4).

(3) 脱髄及び軟化では，急性群，陳旧群共に特 定の症例において中等度以上のびまん性変化がみ られた (Table 5).

以上 3 項目について急性群の中で陳旧性心筋梗 塞を合併している症例を陳旧群に編入し, 新鮮心
Table. 4 血管周囲変化

\begin{tabular}{|c|c|c|c|c|c|c|c|c|}
\hline $\begin{array}{l}\text { 時 } \\
\text { 間 }\end{array}$ & No. & $\begin{array}{l}\text { 年 } \\
\text { 齢 }\end{array}$ & 淡蒼球 & 被款 & 尾状核 & 視床 & 内包 & 外包 \\
\hline \multirow[t]{4}{*}{$I$} & 1 & 48 & $H$ & + & + & - & - & $H$ \\
\hline & 2 & 58 & + & W & + & + . & - & H \\
\hline & 3 & 58 & + & + & - & - & - & - \\
\hline & 4 & 58 & $H$ & $H$ & + & + & - & + \\
\hline II & 5 & 60 & $H$ & H & $H$ & + & - & - \\
\hline \multirow[t]{2}{*}{ III } & 6 & 54 & $H$ & + & + & + & + & + \\
\hline & 7 & 81 & - & H & + & + & + & $H$ \\
\hline IV & 8 & 50 & + & $H$ & $H$ & + & + & + \\
\hline 陳 & 9 & 45 & + & - & $H$ & + & + & - \\
\hline 旧 & 10 & 48 & + & - & - & - & + & - \\
\hline \multirow[t]{6}{*}{ 性 } & 11 & 56 & $H$ & 曲 & $H$ & $H$ & + & + \\
\hline & 12 & 60 & - & + & + & + & - & + \\
\hline & 13 & 69 & + & $H$ & + & H & + & $H$ \\
\hline & 14 & 71 & + & 世 & $H$ & $H$ & + & + \\
\hline & 15 & 72 & + & m & $H$ & - & - & - \\
\hline & 16 & 79 & $H$ & $H$ & $H$ & + & + & $H$ \\
\hline
\end{tabular}

Table. 4 脱髄および軟化

\begin{tabular}{|c|c|c|c|c|c|c|c|c|}
\hline 時 & No. & $\begin{array}{l}\text { 年 } \\
\text { 齢 }\end{array}$ & 炎蒼球 & 被殼 & 尾状核 & 視床 & 内包 & 外包 \\
\hline \multirow[t]{4}{*}{ I } & 1 & 48 & + & - & - & - & - & + \\
\hline & 2 & 58 & + & - & - & - & + & + \\
\hline & 3 & 58 & $H$ & - & - & - & $H$ & $H$ \\
\hline & 4 & 58 & H & + & H & H & W & \# \\
\hline II & 5 & 60 & - & $H$ & - & + & - & - \\
\hline \multirow[t]{2}{*}{ III } & 6 & 54 & + & - & - & - & + & + \\
\hline & 7 & 81 & - & - & - & + & + & + \\
\hline \multirow[t]{2}{*}{ IV } & 8 & 50 & - & + & - & - & + & + \\
\hline & 9 & 45 & $H$ & - & + & + & $H$ & + \\
\hline 陳 & 10 & 48 & + & - & - & - & - & + \\
\hline 旧 & 11 & 56 & 册 & $H$ & $H$ & H & H & $H$ \\
\hline \multirow[t]{5}{*}{ 性 } & 12 & 60 & - & - & - & - & - & - \\
\hline & 13 & 69 & - & - & - & - & - & - \\
\hline & 14 & 71 & W & $H$ & $H$ & $H$ & H. & + \\
\hline & 15 & 72 & - & - & - & - & - & + \\
\hline & 16 & 79 & + & - & - & - & + & - \\
\hline
\end{tabular}

筋梗塞群と陳旧性心筋梗塞群とに分け再検討して みると，(1)においては変更前と比べ両者間に著変 なく，(2)おいては中等度以上の変化がびまん性 に陳旧群に多くなる. (3)においては(2) と同様の所 見であった。

しかし新鮮心筋梗塞群においても(2), (3)の項目 が淡蒼球で軽度ないし中等度にみられる。 


\section{考案および結語}

1）肉眼的変化を認めた例は，すべて軟化性病 変であり, その内訳は小軟化群多発例と小軟化群 小数例より成り, 今回の検索中の $1 / 3$ を占めている.

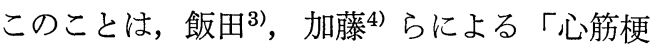
塞は脳出血例より脳梗塞例に合併していることが 多い」という報告を逆の方向から見たことと同じ になる。

2) 肉眼的変化を認めない例において, 大多数 の症例に顕微鏡的虚血性変化が認められた.

今回の検索において心脳卒中例が 2 例あり，1例 は小軟化多発例で他の 1 例は陳旧性梗塞群に属す る肉眼的非軟化例で, 両者共に基底核にはびまん 性の顕微鏡的虚血性変化が認められた.

心脳卒中は藤井ら 2) の報告によると肉眼的病変 を有する場合は大脳皮質及び皮質下の大軟化ある いは出血性軟化が多く, しかも多発性であるとの ことで, 飯田, 加藤らの報告とはやや異なってい る. 心脳卒中例の数が少ないため, 更に症例数を 増加し, 現在大脳の基底核以外の部位についても
詳細に検索中である。

\section{文 献}

1）冲中重雄，村上元孝，西川一郎，関増爾，黒岩義五 郎, 椿忠雄, 新谷博一, 豊倉康夫, 中村晴臣, 石見 善一：心臟と神経症の相関（所謂心脳症候群）に関 する臨床病理学的研究 (第 1 報), 日本循環器学誌, 17, 318 (1953).

2) 藤井潤, 小沢利男; 心璃卒中, 最近医学, $16: 2499$ (1961).

3) 飯田正美, 加藤仁志, 田畑昌夫, 香中洋一, 鈴木恒 道, 矢島権八: 心脳卒中の病理学的研究 II, 脳血管 性病変における心臓の病理学的検索一脳梗塞例につ いて, 動脈硬化, $5: 281$ (1977).

4) 加藤仁志, 飯田正美, 田畑昌夫, 畠中洋一, 鈴木恒 道, 矢島権入 : 心脳卒中の病理学的研究 I, 腷血管 性病変における心臓の病理学的検索一脳出血例につ いて, 動脈硬化, $5: 275$ (1977).

5) 福井庸夫：脳軟化における脳血管硬化性病変の病理 学的研究, 日医大誌, 32:66 (1965).

6) 武谷止孝: 脳の病理組織標本の作り方，第 2 版，金 原出版, 東京, $1,1951$.

7) 武谷止孝: 神経病理組織学入門, 第 1 版, 医学書院, 東京, 76, 1975.

8) 平野朝雄 : 神経病理を学ぶ人の為に, 第 1 版, 医学 書院, 東京, 112, 1976.
質問 岡田了三 (順天堂大内科)

心筋梗塞によるショックの影響はいかがでしょ うか。
回答 池庭 衛

びまん性変化を急性群，陳旧群ともに認めます が，期間の区切りをどのようにするかが問題です。 
Summary

\title{
A Pathological Study of Cardiocerebral Apoplexy and Ischemic Cardioencephalopathy V. Cerebral Lesions in Cases of Myocardialinfarction
}

\author{
Mamoru Ikeniwa, Masami Iida, Hitoshi Kato, Masao Tabata, \\ Tunemichi SuzUKI, and Gonpachi YaJIMA
}

The 1st Department of Pathology, Nippon Medical School, Tokyo, Japan

Cardicerebral apoplexy is known as acute myocardial infarction with apoplexylike symptome. In spite of the symptome, some cases have no macroscopical findings in cerebrum and cerebellum. Others have encephalomalacia. We thought that it was needed to investigate macroscopically and microscopically cerebrum which accompanied myocaldialinfarction. We studied cerebrums of 27 cases.

1) 9 cases had macroscopical small encephalomalacia Another cases had no macroscopical finding. (No subarachnoidal and no cerebral hemorrhage, no large encephalomalacia).

2) Almost of all no macroscopical finding cases had microscopical encephalomalacia. At this investigation, there were two cases of cardiocerebral apoplexy. One case belonged to small macroencephalomalacia group. The other case belongd to no macroencephalomalacia group. Both of them, showed diffuse microscopical encephlomalacia in basal ganglia. Macroscopical finding of cardiocerebralapoplexy, reported by Fujii and others consisted of multiple large encephlomalacias or hemorragic encephalomalacia. Our report was different from this Fujii's opinion. To investigate pathologically cardiocerebral apoplexy, we are studying another lesions of cerebrum in additional cases with consideration of this point.

Key words: cardiocerebral apoplexy, myocardialinfarction, macroscopical encephalomalacia, microscopical encephalomalacia, no cerebral hemorrhage 